\title{
The Role of Key Leadership and Teacher Success on the Effectiveness of SD Negeri in Tulung Selapan
}

\author{
Anie Marliah ${ }^{1 *}$, Bukman Lian², Mulyadi ${ }^{2}$ \\ ${ }^{1}$ SD Negeri 3 Tulung Selapan, Pelembang, Indonesia \\ ${ }^{2}$ Universitas PGRI Palembang, Indonesia \\ *Corresponding author. Email: aniemarliah@gmail.com
}

\begin{abstract}
Principal leadership means all activities carried out by a leader to optimize results and achieve goals. As well as the goal of optimizing the effectiveness of learning. This research was conducted with a harmonious objective, namely to provide a description of the impact of principal leadership and success of teachers on productivity of learning both partially and simultaneously, especially in SD Negeri in Tulung Selapan. Research implementation and reporting are carried out by referring to quantitative research methods. The results of the research conducted state that there is indeed a positively significant impact of the theory leadership on the effectiveness of learning at SD Negeri in Tulung Selapan. The teacher performance variable also has a powerful beneficial effect on the implementation of learning. The same thing was also found in the simultaneous testing, that the key leadership and teacher success together were able to influence the effectiveness of learning positively and significantly.
\end{abstract}

Keywords: Principal Leadership, Teacher Performance, Learning Effectiveness

\section{INTRODUCTION}

Educational institutions are among the institutions that are believed to have had a substantial effect on technology and science growth to date. This is obviously the case because schools continue to change the knowledge and attitudes or character of learners as educational institutions. A high-quality future generation will be created through character learning. It is also very important to promote and organize quality learning in schools.

It is possible to achieve quality learning in different ways, and there are several variables that are known to be able to influence on the quality of learning. If the implementation of learning in class is carried out optimally, the level of learning will be achieved. It is clear that learning efficiency will rely on the teacher's teaching. Qualified teachers can also produce quality students [1]. For this reason, as stated in Law No 14 of 2005 on teachers and lecturers, in particular in Article 1 paragraph (1), a teacher who has a position as a professional educators primarily responsible for training, teaching, directing, guiding, planning, assessing and evaluating early childhood learners through real schooling, proper education and higher school [2].

Similarly, Article 1(3) of the Regulation of the Minister of Education and Culture No 23 of 2017 stresses that teachers are trained educators whose main duty is to educate, teaching, directing, guiding, preparing, Assessment and analysis of students of child development by real schooling, primary education and higher school [3].

If supported by all resources available, teachers should carry out effective learning. In this case, utilization of these tools can be done through the position of a leader. A school principal's leadership will make learning take place efficiently, which is presumed because the power inside the school principal is policies relevant to all learning infrastructure.

As a chief, the principal has the power to control, administer, and provide his subordinates with guidance and instructions about the implementation of learning in the school he leads. For this reason, leadership of the Principal is believed to have an impact on academic success. The job of the principal is to have a positive effect, promote improved outcomes, provide direction in the execution of assignments, carry out directives, 
and become a driving force for teachers, instructional personnel, learners, parents and the community need to work and play a role in achieving the objectives set. As a leader in the school, the principal must have special skills or competencies to boost the performance of his teachers through habit that is regularly carried out at school [4].

As the highest leader of the school unit, the principal should optimize teachers to fulfill their duties such that successful learning can be done. If you trace the mentioned conditions, it can be claimed that the principal's leadership can be a starting point for teachers to optimize their performance. If this occurs, it is also assumed that the learning carried out would be effective.

The success of the teacher is one indicator of the teacher's integrity in carrying out the mandate he has been given. Regulation No 41 of the Minister of National Education of 2007 describes teacher performance as teaching performance resulting from activities carried out by teachers in their key tasks and duties in a concrete exercise, which is a logical consequence of becoming an educational professional.

The description of the mentioned leadership and teacher performance of the principal offers space for inference that these two variables can be presumed to play An crucial part in the implementation of successful learning. Good education will balance students' cognitive and affective knowledge, so that students are equipped with values or characteristic in social life as well [5]. The creation of good education begins with the effectiveness of learning that happens in schools.

Effectiveness is an action or initiative that, through the use of existing resources with the right goal, brings more optimal results. Therefore, if it can function successfully, learning would be more optimal. If the use of resources can be achieved correctly by teachers, a lesson can be classified as successful so that the learning experiences of students become more optimal. The effectiveness of learning would be impacted by the process carried out in the classroom by the educator.

If the teacher has made a qualified learning plan, effective learning will be obtained. This planning can be included in the teacher-aseducator Learning Implementation Plan (RPP). The teaching plan shall be prepared by the teacher individually or in a team as a form of responsibility for planning the implementation of learning in the classroom. With a good management process, learning planning, learning implementation and learning evaluation will be easier to do. Clearly, the effectiveness of learning can be achieved if this can be done properly.

From the initial research carried out by the researcher or known as the preliminary study, the initial information obtained by the researchers was related to the leadership of the principal provided by the teachers in accordance with their respective subjectivity perspectives. As far as the performance of teachers is concerned, it is considered quite good that the effectiveness of learning has not been optimally felt, because sometimes the learning plan documents have not been prepared when the learning activities have taken place during the school year.

If it is emphasized that the researcher's initial finding in the preliminary study was that the level of subjectivity of the principal's leadership was still very strong, according to the narrative of several SD Negeri teachers in Tulung Selapan. Similarly, the completeness of learning administration was not yet available before the learning process began. This shows that the performance of the instructors in charge is not optimal. The fact that the researcher is conducting a preliminary study, which assumes that learning has not taken place effectively, has not been seen as an indicator of the effectiveness of learning, namely the activeness of students participating in learning.

For this reason, a special study is needed on the problems that have been identified. In order to support the implementation of the research, the Principal's leadership, teaching performance and learning efficiency are also described as theoretical and expert opinions. Thus, the aim of this study on the description of the influence of the principal's leadership variables and the performance of teachers on the effectiveness of learning can be optimally achieved.

\section{METHODS}

This research was conducted in primary schools in Tulung Selapan, Ogan Komering Ilir Regency. This research was conducted from July to October 2020. In order to focus the research, the researcher used a quantitative descriptive method, as it is known that this research will test the hypothesis. Sudjana \& Ibrahim [6]. Explanatory analysis is a study that aims to explain a symptom, 
occurrence or event that is occurring at the moment. According to Nazir [7], descriptive type research is carried out with the aim of systematically and accurately describing facts about population-related information. When using a descriptive research approach, the facts obtained from the results of the research will be presented as they should or as they should be.

Confirmed by Sugiyono [8] that quantitative research is a study that obtains data in the form of numbers, or that qualitative data can also be estimated. The quantitative approach is used to measure the variables in this study, namely the variables $X_{1}, X_{2}$ and $Y$, and then to look for the relationship between these variables. Researchers therefore believe that the research method used is the right method for responding to research problems. This research is also referred to as a population study because the entire study population is used as a research sample, i.e. a total of 84 people.

Research data were obtained through observation, documentation and a research questionnaire containing the principal's leadership, teaching performance and learning effectiveness. A total of 55 statements have been prepared by the researcher, of course their validity and reliability have been tested.

\section{RESULT AND DISCUSSION}

\subsection{Testing of Hypotheses 1} below:

The findings of Test Hypothesis 1 will be as

Table 1. Test Results "t test"

Coefficients

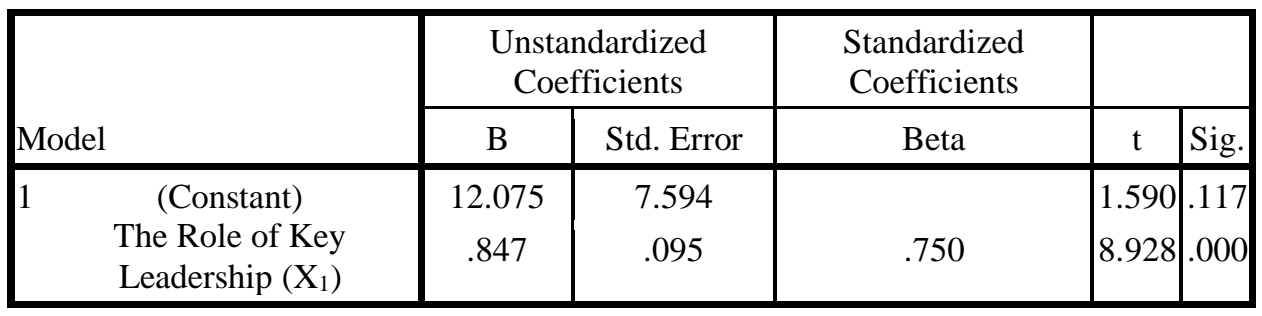

a. Dependent Variable: Effectiveness (Y)

The $\mathrm{t}$ value for the Principal Steering Variable is $8.928>t$ table is 1.999 , which means that the alternative (Ha) hypothesis for the Test Hypothesis 1 is accepted. It is therefore claimed That the

performance of the Principal has a significantly positive effect on the effectiveness of learning in SD Negeri, Tulung Selapan District, Ogan Komering Ilir Regency.

Table 2. The Determinant's Coefficient (H1)

\begin{tabular}{|c|c|c|c|c|}
\hline Model & $\mathrm{R}$ & $\begin{array}{c}\mathrm{R} \\
\text { Square }\end{array}$ & $\begin{array}{c}\text { Adjusted } \\
\text { R } \\
\text { Square }\end{array}$ & $\begin{array}{l}\text { Std. Error } \\
\text { of the } \\
\text { Estimate }\end{array}$ \\
\hline 1 & $.750^{\mathrm{a}}$ & 0.563 & 0.555 & 2.67755 \\
\hline
\end{tabular}

Source: data processed (October, 2020)

The correlation coefficient or level of relationship between the Principal's leadership and the effectiveness of learning is $75.0 \%$ and is included in the Strong Relationship category. The determining factor or magnitude of the influence of the principal's leadership variable on the effectiveness of learning is $56.3 \%$, which means that it has a high enough influence.

\subsection{Testing of Hypotheses 2}

The results obtained from Test Hypothesis 1 are as follows: 
Table 3. Test Results "t test"

Coefficients $^{\mathrm{a}}$

\begin{tabular}{|c|c|c|c|c|c|}
\hline \multirow[b]{2}{*}{ Model } & \multicolumn{2}{|c|}{$\begin{array}{l}\text { Unstandardized } \\
\text { Coefficients }\end{array}$} & \multirow{2}{*}{$\begin{array}{r}\begin{array}{r}\text { Standardized } \\
\text { Coefficients }\end{array} \\
\text { Beta }\end{array}$} & \multirow[b]{2}{*}{$\mathrm{t}$} & \multirow[b]{2}{*}{ Sig. } \\
\hline & B & Std. Error & & & \\
\hline $\begin{array}{c}\text { (Constant) } \\
\text { Teacher Success } \\
\left(\mathrm{X}_{2}\right)\end{array}$ & $\begin{array}{c}13.226 \\
.840\end{array}$ & $\begin{array}{c}8.359 \\
.105\end{array}$ & .712 & $\begin{array}{l}1.582 \\
7.973\end{array}$ & $\begin{array}{l}.119 \\
.000\end{array}$ \\
\hline
\end{tabular}

a. Dependent Variable: Effectiveness (Y)

Source: data processed (October, 2020)

$\mathrm{T}_{\text {count }}>\mathrm{t}_{\text {table }} ; 7,973>1,999$. Based on this, it is concluded that the alternative hypothesis is accepted, which means that the performance of teachers has a positive and significant effect on the effectiveness of learning in SD Negeri, Tulung Selapan District, Ogan Komering Ilir Regency.

Table 4. The Determinant's Coefficient $\left(\mathbf{H}_{2}\right)$

\begin{tabular}{lcrrr}
\hline Model & R & $\begin{array}{c}\text { R } \\
\text { Square }\end{array}$ & $\begin{array}{c}\text { Adjusted } \\
\text { R Square }\end{array}$ & $\begin{array}{c}\text { Std. Error } \\
\text { of the } \\
\text { Estimate }\end{array}$ \\
\hline 1 & $.750^{\mathrm{a}}$ & 0.563 & 0.555 & 2.67755
\end{tabular}

a. Predictors: (Constant), Teacher Success

Source: data processed (October, 2020)

The coefficient of association between Ogan Komering Ilir Regency is $50.6 \%$ and is instructor success and learning productivity is $71.2 \%$. The extent of the interaction belongs to the next group. The magnitude of the influence of teacher success variables on the effectiveness of learning in SD Negeri, Tulung Selapan District, included in the range of high enough influence.

\subsection{Testing of Hypotheses 3}

Hypothesis testing 3 is a simultaneous or joint test hypothesis.

Table 5. Test results for "Test $F$ "

ANOVA $^{\mathrm{b}}$

\begin{tabular}{|l|c|c|c|c|c|}
\hline Model & Sum of Squares & df & Mean Square & F & Sig. \\
\hline 1 Regression & 617.250 & 2 & 308.625 & 47.212 & $.000^{\mathrm{b}}$ \\
Residual & 398.754 & 61 & 6.537 & & \\
Total & 1016.004 & 63 & & & \\
\hline
\end{tabular}

a. Predictors: (Constant), Professionalism $\left(\mathrm{X}_{1}\right),\left(\right.$ Constant), The Role of Key Leadership $\left(\mathrm{X}_{2}\right)$

b. Dependent Variable: Effectiveness (Y)

Source: data processed (October, 2020)

$F_{\text {count }}$ of 47.212> $F_{\text {Table }} 3.148$, which means that there is a positive and significant influence of primary leadership and teaching performance on the effectiveness of learning in SD Negeri, Tulung
Selapan District, Ogan Komering Ilir Regency. The magnitude of the influence of the two independent variables on the dependent variable can be seen in the table below. 
Table 6. The Determinant's Coefficient $\left(\mathrm{H}_{3}\right)$

\begin{tabular}{lcccc}
\hline Model & R & $\begin{array}{c}\mathrm{R} \\
\text { Square }\end{array}$ & $\begin{array}{c}\text { Adjusted } \\
\mathrm{R} \\
\text { Square }\end{array}$ & $\begin{array}{c}\text { Std. Error } \\
\text { of the } \\
\text { Estimate }\end{array}$ \\
\hline 1 & $.779^{\mathrm{a}}$ & 0.608 & 0.595 & 2.55675 \\
\hline \multicolumn{4}{l}{$\begin{array}{l}\text { a. Predictors: (Constant), Professionalism, The } \\
\text { Role of Key Leadership }\end{array}$}
\end{tabular}

Source: data processed (October, 2020)

As much as 0.779 , which means $77.9 \%$ together, the leadership and teaching performance of the Principal have an impact on the effectiveness of learning in SD Negeri, Tulung Selapan District, Ogan Komering Ilir Regency. It falls within the category of a close relationship. As much as 0.608 , which means that the Principal's leadership and teaching performance together have a $60.8 \%$ impact on the effectiveness of SD learning in the Tulung Selapan District of Ogan Komering Ilir Regency and are included in the category of high enough influence.

\subsection{Effect of Leadership of the Principal on The Effectiveness of Learning}

Hypothesis testing conducted by researchers is known to have a $\mathrm{t}$ value of $8.928>\mathrm{t}$ for the Principal Leadership variable, namely 1.999, which means that the alternative hypothesis $\left(\mathrm{H}_{\mathrm{a}}\right)$ for the Test Hypothesis 1 is accepted. It is therefore claimed that the leadership of the Principal has a positive and significant impact on the effectiveness of learning in SD Negeri, Tulung Selapan District, Ogan Komering Ilir Regency.

The results of this study confirm several previous studies, such as those conducted by Nurhafifah, Djasmi and Ambarita [9], that the performance of the principal and teacher have good and essential impact on the effectiveness of the school. Although previous research focused on general school effectiveness, this value is, of course, derived from the efficiency of learning that takes place in the classroom. That is why there is a significant relationship between the relevance of this study.

Other research that is also supported by these findings is research conducted by Achmad [10], which states that key leadership and teacher success can have a high impact on the effectiveness of Islamic learning. It is clearly the same as this study that the leadership of a principal who is supported by the performance of teachers is capable of optimizing the effectiveness of learning in general. Similar to Banani's research [11], which states that primary leadership affects the ability of teachers to achieve learning efficiency.

It is therefore appropriate for the principle to be guided in a wise manner so that the effectiveness of learning can continue to increase and improve.

\subsection{Effects of Teacher Performance on The Effectiveness of Learning}

This report further confirms the findings of the studies carried out by Nurhafifah, Djasmi \& Ambarita [9] that the performance of teachers has a positively significant influence on the school effectiveness. That's why a teacher needs to be able to optimize his potential so that his performance can be improved. This is also in line with the research carried out by Achmad [10], the teaching success has a good impact on the efficacy of Islamic religious learning. This is very encouraging, which means that in order to optimize the effectiveness of learning, you must first optimize the performance of the teacher concerned.

Irwana [12], which states that the performance of teachers can contribute to a positive impact on school efficiency in elementary schools, is another research that becomes the research reference and also the results supported by this research. As this research has been conducted, the consistency of these variables can be seen in influencing the effectiveness of learning. 


\subsection{Effects of Leadership of the Principal and Teacher Performance on The Effectiveness Learning}

The coefficient test performed by the researcher was 0.608 , which means that the leadership and teaching performance of the principal jointly affect the effectiveness of SD learning in the Tulung Selapan District of Ogan Komering Ilir Regency by $60.8 \%$ and are included in the category of high enough influence.

The results of this study also support several previous studies, such as research conducted by Zamroni, Nurkholis, and Yuliejantiningsih in 2017 that leadership style is able to have a positive impact on teacher performance, which will have positive implications for the implementation of learning so that it becomes more effective.

\section{CONCLUSION}

Depending on the outcomes of the data review and the analysis and summary of the data of this report, it is concluded that (1) the leadership of the Theory has a significantly positive effect on the outcomes of learning; (2) the performance of teaching staff has a positive and significant effect on the outcomes of learning in SD Negeri, Tulung Selapan District, Ogan Komering Ilir Regency; 3) principal leadership and the success of teachers together has a positive and important impact on productivity. of learning in SD Negeri in Tulung Selapan District, Ogan Komering Ilir Regency. The magnitude of the effect simultaneously is sixty point eight percent and is included in the fairly high impact category.

\section{ACKNOWLEDGMENTS}

Researchers would like to thank all those who have helped to complete this work, particularly the PGRI Palembang University and the Ogan Komering Ilir Regency Education Office.

\section{REFERENCES}

[1] Hanim, H., \& Rahmadoni, J. (2020). Determination of Lecturer Reception Using Analytical Hierarchy Process (AHP). Journal of Applied Engineering and Technological Science (JAETS), 1 (2), 136-141.

[2] Pemerintah Republik Indonesia. (2005). Undang-Undang Nomor 14 Tahun 2005 tentang Guru dan Dosen [Law Number 14 of
2005 concerning Teachers and Lecturers]. Jakarta: Pemerintah Republik Indonesia.

[3] Kementerian Pendidikan dan Kebudayaan. (2017). Peraturan Menteri Pendidikan dan Kebudayaan Nomor 23 Tahun 2017 tentang Hari Sekolah [Regulation of the Minister of Education and Culture Number 23 of 2017 concerning School Days]. Jakarta: Kementerian Pendidikan dan Kebudayaan.

[4] Kristiawan, M., Safitri, D., \& Lestari, R. (2017). Manajemen Pendidikan[ Education Management]. Yogyakarta: Deepublish.

[5] Sukatin. (2016). Manajemen supervisi dalam pendidikan (studi kasus di MAN Model Jambi) [Management supervision in education (case study in MAN Model Jambi)]. HIKMAH: Jurnal Pendidikan Islam, Volume 5 Nomor 2, 221-240.

[6] Sudjana, N., \& Ibrahim. (2010). Penelitian dan penilaian pendidikan [Educational research and assessment]. Bandung: Sinar Baru Algesindo.

[7] Nazir, M. (2011). Metode penelitian [Research methods]. Jakarta: Ghalia Indonesia.

[8] Sugiyono. (2017). Metode Penelitian Kualitatif, Kuantitatif dan $R \& D$ [Qualitative Research Methods, Quantitative and $R \& D]$. Bandung: Alfabeta.

[9] Nurhafifah, Djasmi, S., \& Ambarita, A. (2016). Pengaruh kepala sekolah, budaya, kinerja guru terhadap efektivitas sekolah [The influence of school principals, culture, teacher performance on school effectiveness]. e-jurnal unila.

[10] Achmad, A. (2015). Pengaruh Kepemimpinan Kepala Sekolah dan Kinerja Guru terhadap Efektivitas Pembelajaran Agama Islam [The Influence of Principal Leadership and Teacher Performance on the Effectiveness of Islamic Learning]. Bandung: UIN Sunan Gunung Djati.

[11] Banani, M. T. (2017). Pengaruh Kepemimpinan Kepala Sekolah terhadap Kompetensi Guru dalam Mewujudkan Efektivitas Pembelajaran [The Influence of 
Principal Leadership on Teacher Competence in Realizing Learning Effectiveness. Jurnal Pendidikan UNIGA, Volume 11 Nomor 1.

[12] Irwana, A. (2015). Kepemimpinan Visioner Kepala Sekolah dan Kinerja Guru terhadap Efektivitas Sekolah di Sekolah Dasar [Principal's Visionary Leadership and Teacher Performance on School Effectiveness in Primary Schools]. Jurnal Administrasi Pendidikan, Volume 22 Nomor 2. 